\title{
A RESEARCH ON MANAGERIAL ETHICS PRACTICES IN TURKISH MEDIA ORGANIZATIONS
}

\section{Ali Bülent KUTVAN ${ }^{1}$}

\begin{abstract}
Recent advances in information technologies have allowed easier and faster access not only to technical information and production, but also social, cultural and ethical information, viewpoints and assessments by the public at large -without the scrutiny of a centralized administration. This ongoing process has paved the way for a new people-oriented ethics to emerge, while, underlining the importance of such concepts as human rights, equality and freedom. Managerial ethics' sphere of influence is not limited to the business world. It is, in fact, concerned with the every aspect of social life. In this regard, it functions at the core of socio-economic process in creating public benefit while solving and preventing problems.

How managerial ethics, as an applied field, can be implemented within a methodology in organizational process, and how to solve the problems that may arise along the way is an important field in modern administrative sciences. It is of special importance that, the media organizations, commonly referred to as the fourth power in democratic societies, have an internal system of governance driven by managerial ethics and its practices. This research is the investigation of the relationship between existence of managerial ethics codes and existence of ethics training programs in Turkish media organizations through questionnaires.
\end{abstract}

Keywords: Ethics, Managerial Ethics, Corporate Social Responsibility, Business Ethics, Media Organizations

JEL Classification: M14

\section{TÜRK BASIN IŞSLTMELERINDE YÖNETSEL ETIK UYGULAMALARI ÜZERINE BİR ARAȘTIRMA}

ÖZ

Yönetsel etik, iş yaşamının (çalışanlardan tüketicilere) yanı sıra bütün toplum kesimlerini ve çevreyi ilgilendirmektedir. Bu anlamda, yönetsel etik, toplumsal boyutta sosyo-ekonomik süreçte karşılaşılan sorun ve çelişkileri çözmede ve/veya önlemede kamusal yarar açısından önemli bir işleve sahiptir.

Bir uygulamalı etik alanı olan yönetsel etik'in örgütsel süreçlerde metodolojik bir program dahilinde nasıl uygulanacağı, uygulama sürecinde ortaya çıkan sorunları ve bu sorunların nasıl ve hangi yöntemler ile çözülebileceği çağdaş yönetim bilimi için önemli bir uygulama alanıdır. Demokratik toplumlarda bir tür toplumsal denetim mekanizması olan basın işletmelerinin kendi yönetsel süreçlerinde yönetsel etik kavram ve uygulamalarına sahip olmaları özel bir önem taşımaktadır.

Bu çalışmada, Tam sayım yöntemi ile Türk medya kuruluşlarının yönetsel etik kavram ve uygulamalarından ne derecede yararlandıkları ve yönetsel etik eğitimine ne derecede önem verdikleri araştırılmıştır.

Anahtar Kelimeler: Etik, Yönetsel Etik, İş Ahlakı, Kurumsal Sosyal Sorumluluk, Basın İşletmeleri

JEL Sinıflandırması: M14

${ }^{1}$ Asc. Prof. Dr. Nişantaşı University, kutvan@gmail.com 


\section{Introduction}

Even though ethics is one of the most mentioned subjects of the daily life in Turkey and also in the World, is not so much accentuated by the academic world. However, this concept has gradually gained its importance in the managerial discipline especially after 1980's. The main feature is the raise of the social sensitivity and the public (especially the non-governmental organizations) pressure due to the social-cultural structures changing according to the technological improvements in knowledge and communication. In this context, considering corporations as social systems as well as economic beings has become a highly acknowledged general notion.

It is necessary to emphasize here that the conflicts caused in the social life by the dilemma between managers and managed people and the economic imbalance, which can be described as primary (basic) ethics problems, cannot be totally solved as the causes cannot be totally eliminated. It is expected to have an inversely proportional increase in the public ethics due to the decrease in these differences.

Almost every problem handled in the scope of managerial ethics is actually the reflection of the field of primary (basic) ethics problematic. In other words, secondary ethical problems as corruption, bribe, personal benefit, false advertisement are the results of primary ethical problems and come out as different images/reflections of primary problems.

Problems handled in the scope of managerial ethics will continue to exist as long as the solution of the primary problems of ethics gets difficult. The secondary problems which are the reflections of basic social problems will be eliminated in line with the elimination of these public matters.

The adoption of the managerial ethics in this context by the companies is important in the sense of protection and improvement of social ethics.

There is a limited amount of holistic literary studies or researches in the field of managerial ethics. In this respect, the aim of this study is to handle managerial ethics in all aspects and offer to the information and evaluation of the academics, managers and all others who are concerned of the matter.

The last chapter, which is the research part of our study, the application of managerial ethics in the organizational structure of the press associations and the stipulation of the press associations concerning managerial ethics are examined.

It is necessary here to indicate that, there are many studies on the professional ethics about the employees of the press under the title of "media ethics". In our study, ways of applications of the managerial ethics as a program is handled in the scope of administrative sciences. 
Interviews and surveys are made covering managers of thirty three national newspapers. Target of the research is to exemplify the relation between managerial ethics' codes and appliance of managerial ethics' training programs in the extent of press corporations.

\section{Basic Concepts \\ 2.1.Morality and Ethics}

The words "morality" and "ethics" are used in the same meaning in daily Turkish. But these two words have nuances in meaning. Morality (Ahlâk) comes from the Arabic word "hulk" which means habit, nature or moral fibre of a person as formed by genesis. (Uzun, 2009; 19)

Morality is a discipline related with the good and the bad along with the spiritual duties and responsibilities. (Özgener; 2009; 6)

The word "ethics" derived from the Greek word "ethos" meaning "character". Ethics as a branch of Axiology (philosophical study of value) is one of the five main branches of philosophy.

Philosophical studies are usually studied under five subtitles; (1) metaphys$i c s$, examines the nature of reality; (2) logic, studies the ways and principles of thinking; (3) epistemology, studies knowledge and concepts of knowledge; (4) esthetics, studies the meaning and image of beauty; (5) ethics, studies the formation of moral values and the principles of "good" and "bad". (Özgen, 2006; 47)

Ethics which is also called as the "ritual science", is the branch of philosophy that studies the ritual and moral human relationships, behaviours and opinions.

The aim of ethics is to explain measurements of good and bad associated with the past or today. (Lamberton ve Minor, 1995: 409)

It is the branch of philosophy that studies ritual or moral human relationships, their behaviours and opinions. (Çalışlar, 1983; 10)

Ethics is also named as moral philosophy by the Western philosophical tradition. In Turkish it is used as moral science and sometimes ethics and moral are used in the same meaning.

Since morality is described as a human fact, it undertakes an important function on socialization. In other words morality is an important component of the socialization process of human beings. (Özgen, 2006; 26)

All social sciences are concerned with the ethical roots of the human behaviour in different levels. For instance, it has reflections and influence; on economy depending on the sharing problems of limited sources, on political sciences depending on the role in establishing the civil power and the government potency, on managerial ethics in the context of organization customs and business ethics, on law 
by the founding of legal ethics and principles and on anthropology in the context of confusions and conflictions experienced during the comparison process of two different cultures.

Apart from the social sciences, ethics is named as the environmental ethics in ecology and the bio-ethics in biology.

Ethics is the branch of philosophy that studies morality in a systematic way. Ethics asks various questions and examines them. It is categorized according to the subject examined as; behaviour of a person in a definite situation is included in the field of "applied ethics", ways of someone in confirmation of a moral situation or vision in "normative ethics" and the comprehension of someone the original structure of ethics and morality in "meta-ethics".

For instance, the appropriateness of the attraction of the people by the media in a partisan way is discussed in the scope of "applied ethics". The most popular question in "normative ethics" is, if someone lies to protect another one, will this be considered within morality or not. In "meta-ethics", it is asked and examined if morality is only the expression of a person's special preferences; is everything relative or how the existence of "good" is approved by us.

In other words, studies that include moral estimations and suggestions are called "normative". In the "meta-ethics" method of study, "ethics" is used in the meaning of examining the words and concepts people use in cases of deciding, suggesting something, warning someone or assessing someone's behaviour.

In "meta-ethics" the utilization, the meaning and the nature of these moral suggestions and the things that form morality are studied despite the fact that in "normative ethics" moral suggestions are made directly.

\subsection{Social Responsibility Concept}

In spite of the incredible improvements in science and technology, as the individual has become more and more stranger to his family, his environment, the society, to the world and even to himself, the bound in the offices and in the collective working sense has been loosened, the nature and natural sources are destructed irresponsibly; some company leaders that are aware of the corporate ethics have come together towards the end of 1980's against these destructive events and formations and declared that they accept struggling against the idea "Biggest profit within the shortest time at any cost" as their principle.

The first organization of this development is the "Social Venture Network USA" established in 1987 which consisted of nearly 1000 private sector companies most of them being American. (Özkol, 2007; 73)

Following this general frame we may go on with the definitions made by different writers and academicians about the Institutional Social Responsibility: 
Social responsibility may be defined as adopting the restriction of the companies from unsafe activities through the whole process from production to consumption and the policies, procedures, movements that force companies to work in favour of people as a principle. (Özgener, 2009; 161)

Another definition covers the social responsibilities of companies that force to restrict unsafe effects resulting from the economical activities and that contribute to actions for the safe and comfort of people and activities that aim accordance with community alterations. (Nalbant, 2005; 194)

A different description says that the social responsibility of a corporation should be to pay as much attention to the social consequences of their decisions as they are sensitive to the economical effects. (Aldag ve Stearns, 1991; 112)

Robertson and Nicholson suggest that the social responsibilities of a corporation are defined under three main principles. (Özgener, 2009; 164) These principles are;

Legality Principle; is based on the awareness of the corporation regarding its social responsibilities depending on its institutional functions and activities. This principle is associated with the relation between the company and the society and makes the needs of the company more specific.

Public responsibility principle: A company according to its organizational functions can overtake social responsibilities interrelated with its fields of primary and secondary interest.

Therefore, the responsibilities of a company are limited by problems directly result from their actions and benefits.

Managerial discretion right: This principle is related to the managers as they are the individual actors of functions and morality. Basically, this principle defines the responsibilities of the managers in choosing activities to be planned in order to succeed in social duties.

\subsection{Social Sensitivity}

The concept "social sensitivity" basically can be expressed as the corporations' evolving policies on social issues and attention to these matters.

Actually this approach states that "social responsibility concept" stands for the leading role of the enterprises in social activities and also in the inclination in prosperity besides the obligation of fulfilling the laws and the requirements of people. (Sayiner, 2005; 28)

There are two main approaches related to the social responsibility concept.

The first is dedicated on the ways of increasing singular social sensitivity of enterprises which relies on the micro level analysis while the other approach favours 
macro level that sustain the idea that the government is obliged to form the social aims of the country.

\subsection{Social Control}

It is much more questioned nowadays that the enterprises are concerned with social issues actively, they fulfill their social responsibilities and they have social sensitivity as the communities are much more organized and have an increasing level of sensitivity. In this context, it is a subject of social controls how enterprises perform their social responsibilities.

Social control is an analysis made on an enterprise's level of accomplishment of its aims in social responsibilities.

Social control mechanism measures, evaluates and reports the social performance level of the enterprise periodically in all the fields whether related to the business area of the company or not. (Rachman, 1996; 63)

Social control provides the managers opportunity to evaluate and improve the efforts and activities related to their social responsibilities and social sensitivities. Besides, people have the occasion to check the international appropriateness of the policy and application of the social responsibilities of enterprises by the help of these social control organizations.

Consequently, it becomes possible to evaluate the people's benefit due to the social activities and social control mechanisms and to compare the alternative social policies and movements.

\subsection{Managerial Ethics Concept}

Academic studies have been concentrated on managerial ethics since 1970's. The number of essays and educational books on managerial ethics has increased by 1980's.

Managerial ethics has emerged as a result of efforts made to conciliate the advantages of the enterprises, customers, share owners and the managers which stand in competition with each other. Managerial ethics suggests the improvement of the responsibility idea for the managers supplying the moral principles. (Özgener, 2009; 95)

Managerial ethics, studies the behaviour standards of people and norms that organize and lead the relationship between workers and the companies they work for and dissimilar to the thoughts that suppose enterprises should work hard to gain much with main target of a maximum profit, examines, evaluates and comments on the enterprises' activities in respect of morality. (Flippo ve Gary ve Munsinger, 1982; 71) 
Managerial ethics is defined as the moral principles and behaviour standards improved by the managers or organizations in order to success in business and achieve the organizational targets. (Bartol ve Martin, 1994; 102)

Managerial ethics, tries to categorize the good and the bad as main issues of ethics in the attitude of managers regarding the workers and the work. In this context, we may say that, the main target of the managerial ethics is to define the managers behaviour as "how it should be" and as "how it should not be" by a normative methodology. (Dağdelen, 2005)

The key factor of launching the idea "Managerial Ethics" is the clash of interests. Generally, if we assume that every moral issue is a result of a conflict, the problems of managerial ethics are the results of the divergences between the enterprises, their share owners, workers, customers, consumers, suppliers and the people. If these conflicts did not exist, there would be no need to the managerial ethics concept. Subsequently, managerial ethics has become a method used in solution of these conflicts of interests.

\section{Differences Between "Social Responsibility" and "Managerial Ethic" Concepts}

It is essential to put forward the differences between the concepts "social responsibility" and "managerial ethics", in order to accomplish the managerial ethics concept. Generally, both these differences are ignored and used mistakenly in place of each other.

The main difference between "social responsibility" and "managerial ethics" is the enterprise's activities under the inspiration of social responsibility, besides the internal responsibilities. The activities and projects generated under social responsibility inspiration, does not mean that the company, in its internal procedures, is acting in line with managerial ethics and that, ethical criteria is considered at all times throughout the decision processes.

It is obvious that, some activities and practices may occur as an obligation resulting from both managerial ethics and social responsibilities. For instance, the fact that an enterprise having employees of different religions, ethnic groups, different genders or disabled persons can be included in both the area of social responsibilities and managerial ethics; but, a project developed to give the disabled people special cars, is considered in the scope of social responsibility performances of the company.

If we briefly say again, "managerial ethics" performance of the enterprise is related with the ethical appropriateness of its whole sum of activities. On the other hand, "social responsibility" performance is related to the social activities and projects developed for the environment and the public. The social responsibility performance of the enterprise does not show its ethical performance. 


\section{The Institutionalization Process of Managerial Ethics}

Following the definition made of the importance of culture in the description process of ethical behaviour, we will handle the practising process of managerial ethics programme in the organizations and the institutionalization process of these appliances.

Figure: 1 The Institutionalization Process of Managerial Ethics

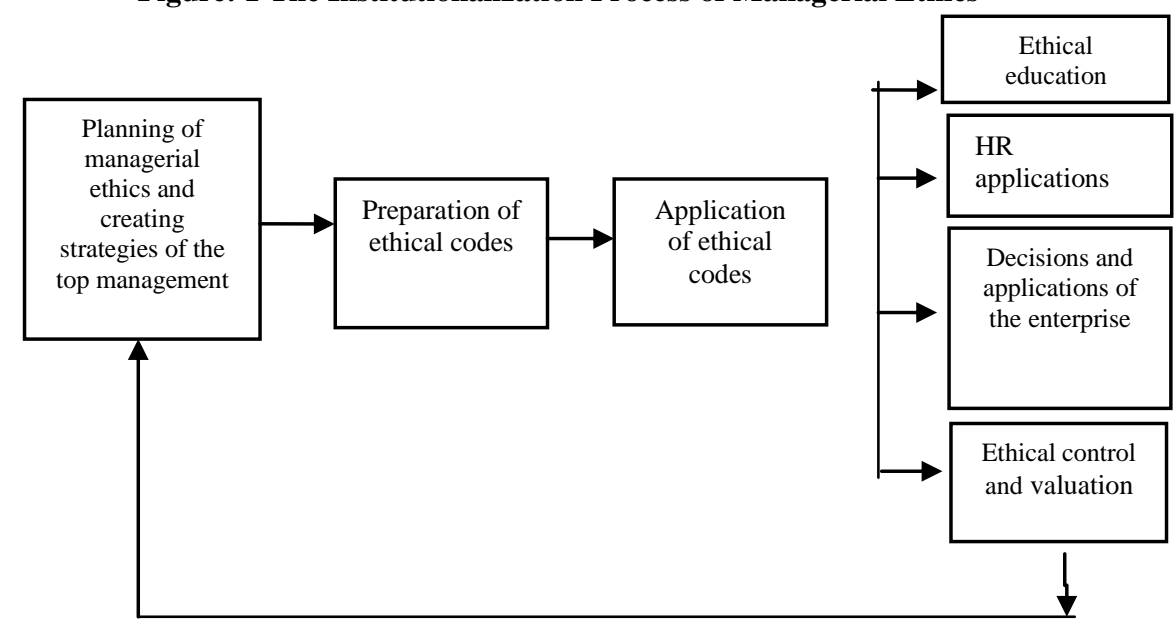

Referance: Arslan and Berkman, 2009;111

\subsection{Kohlberg's Ethical Process Theory}

We should have a short look at the approaches of L. Kohlberg's who has developed theories on the ethical progress levels of individuals before we proceed with the information regarding the application process of the managerial ethics programs in organizations. Lawrence Kohlberg who is one of the professors of Harvard University is involved in moral education subjects since early 1970's. Kohlberg's moral progress theory is based on the thoughts of the Swiss physiologist Jean Piaget and the American philosopher John Dewey and has been influenced by James Mark Baldwin (Ülgen, 2003; 14)

When we look at Kohlberg's personal moral development model; (Ülgen, $2003 ; 15)$ 
Figure:2 Lawrence Kohlberg's Personal Moral Development

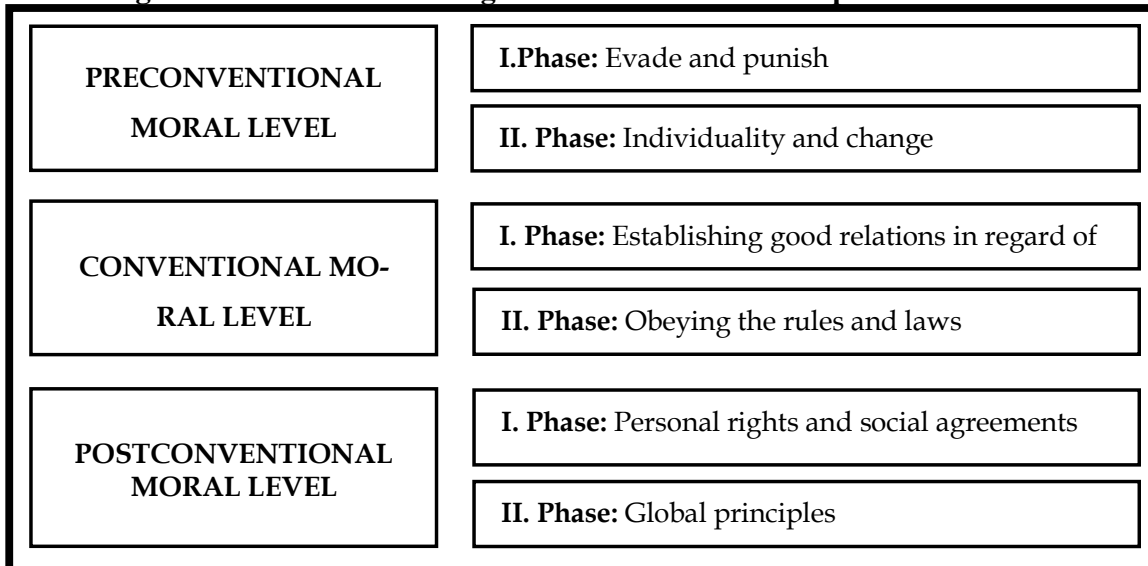

Referance: Robert N. Barger, "A Summary of Lawrence Kohlberg's Stages of Moral Development”(online), htpp://www.cs.unca.edu/ manns/LawrenceKohlberg.doc)

\section{Preconventional moral level:}

In this level there is an absolute loyalty in authority. In this phase, as individuals are afraid of punishment, they obey the rules. Avoiding punishment and approaching towards awarding is a typical behaviour of this phase.

This phase suggests a leadership of an apparent authority in organizational structure. Besides, in this phase, individual advantages are maximized and people choose to act appropriate to ethical rules in favour of their benefits.

\section{Conventional moral level:}

In this level the individual acts in accordance with moral rules so as to be in harmony with people. In other words, the individual behaves in accordance in this phase in order to protect the moral values of the society. In this phase individuals learn to fulfil the expectation of their families, their colleagues and their social environment which is defined as good behaviour by the society. In this phase, it is important to fulfil the social and interpersonal responsibilities.

In organizational structure, a management style that is based on team work and collaboration is used. In the second phase of this level, it is important for the individual to behave in accordance with the laws and perform his professional duties at utmost.

\section{Post conventional level:}

In this phase, individuals protect the moral values against the attitude and thoughts of the majority. If there is an ethical conflict, individuals choose to behave according to ethical rules by taking the risk of the sanctions applied by the majority. 
The second phase of this level depends on universal ethical principles and conscience.

For instance, a manager who resists performing the directions of his superiors because he thinks that it would be in harm of others shows the level of his moral progress. Leading managers with this level of morality concentrate on the needs of their employee and to supply these needs they utilize the "transformative" type of leadership. (Ülgen, 2003; 16)

According to Kohlberg, most of the leading managers are in the second level of moral progress. There are few managers who cannot pass the first level. Leaders that are in the third level may act liberated and ethical, without being concerned about the needs of the individuals in or out the organization. These leading managers will decide ethically whatever the results of their decisions will affect the organization. According to Kohlberg and Piaget most of the moral progress is built up and developed due to the social improvement. Individuals pass these levels one by one. There happens to be no leaps among levels. (Ülgen, 2003; 16)

Managerial ethics program tends to improve the moral level of the individuals working for the enterprises. Individuals have different moral levels and therefore the ones that do not have the required moral qualifications must be eliminated during the personnel selection process.

During the application process of managerial ethics program there are two vital things to be considered. Firstly, the moral level of the individuals must be improved by the managerial ethics program. Secondly the program must be connected with the daily activity schedule. (Sayiner, 2005; 107)

Lisa Dercks has examined the problems resulting from the immoral actions during the 1999 Europe Commission in her article (2001) and has suggested an ethical program to the commission in this context. (Sayiner, 2005; 108)

This program consists of;

- Determination of organizational values;

- Improvement of ethical behaviour codes,

- Constitution of an ethical commission,

- Creation of a program on adoption of ethical principles which is obliged to be attended,

- Placement of ethical evaluation concept in performance system,

- Arrangement of ethical education programs for the leading managerial team,

- Constitution/ understanding process of a social control organization in order to control the working of the system process.

In this scope, we can define the organizational process of managerial ethics briefly as follows: (Arslan ve Berkman, 2009; 112) 


\section{Superior Management has to;}

- Believe in the necessity,

- Demonstrate leadership,

- Make training study,

- Be concerned of a long term (3-5years) perception,

- Adopt a large scoped approach (covering all the activities and people)

Preparation of Ethical Codes;

- Determination of the values/priorities of the company

- Evaluation of the related codes

- Development of the main aspects of the code that fits the company best (in respect of the sector, activities, culture, share holders and environmental relations)Having external professional support if needed during these processes

- Having internal support from different levels in the company during these processes at the suitable time

- Having detailed arrangements for the people in charge of special duties as well as the general principles in the code

the code

- Designation of the personnel who will be responsible of the working of

- Definition clearly of the sanctions and procedures in case of peculiarities associated to code and behaviour principles

\section{Ethical Code Application;}

- Making sure that all workers are given the complete text of the code with the explanations of its importance, necessity and benefits.

- Providing the names and communication information of the ethical staff in case of probable problems.

\section{Ethical Commission and the Commissioners;}

- Constitution of the ethical commission for the ethical construction (There can also be members out of the company in the commission)

- Determination of the ethical commissioners in departments (Ombudsman or an ethical consultant may name the staff)

- Variation and contact easiness of the means of complains.

\section{Ethical Training;}

- Information about the importance, necessity and benefits

- Incorporation with all the staff including the superiors

- Application of different programs for workers of different levels and positions (regarding the content, method and the teacher) 


\section{Human Resources Applications;}

- Spreading of the applications which award ethical behaviour or punish unethical behaviour

- Making ethical behaviour be included in performance valuation essentials

- Having annual ethical valuation

Decisions and Applications of the enterprise;

- Ethics being relevant for all the decisions and applications

- Healthy relationships between the share holders and the society sibility projects

- Contribution to the quality of public interest by means of social respon-

\section{Ethical Control and Evaluation;}

- Controlling and evaluating of all ethical processes if possible by external companies and publishing of by these documents

- Description of performance and if necessary making equipment and procedure revisions in aspect of "ethical management" and "management of ethics"

It is possible to make available the managerial ethics program institutionalized in the organization, by precisely following the process mentioned above.

\section{A research for managerial ethics practices in Turkish media}

organizations:

\subsection{Aim and Importance of the Research:}

The basic aim of this research is to examine the application of managerial ethics concept in press enterprises' organizational structure.

In an organization which performs a basic public service as news production, managerial ethics approach, besides business ethics, is very important and determining in respect of press enterprises.

It is only possible when enterprises adopt and practise ethical approach to perform their activities and decisions in the scope of ethical rules. So the enterprises' publishing some principles or rules under the name "ethical codes" is not the main issue in this context, it is the enabling of the employees to adopt and discuss these principles by means of training programs.

It is intended mainly in this study to state how the press enterprises apply managerial ethics and how much space takes the managerial ethics training in their programs. 
There are very limited studies made related to the managerial ethics in Turkey. As we refer to literature, we see that most of the studies related to the managerial ethics are realized in USA, England, Canada and Germany. These studies are generally on the occurrence of ethical codes, the ethical and unethical behaviour of organizations, and the ethical performance perception in respect of tconsumption assessments.

(Associated with these studies, see; "Journal of Business Ethics, Volume 1/1982-Volume 99 / 2011; ISSN: 0167-4544)

As far as the relevant literature is concerned there is not another study on managerial ethics codes, managerial ethics appliers, unethical practise reports and ethical tendencies of press enterprises handled all together. So this makes our research more significant.

In this context, the four main components of managerial ethics fact, managerial ethics codes, ethical commitees, unethical practise reports and their feedbacks and results of unethical applications and managerial ethics training programs/methods and evaluation of results form the main structure of our study.

We have tried in this study to identify the present situation of the press enterprises in respect with their managerial ethics, their managerial ethics application and training programs.

In this context, the results and data of the research is valuable for the other researchers, experts and academics as they provide an opportunity of comparision.

Examining managerial ethics through press is another essential point as the social/managerial and economical degenerations in the society are brought to public attention by press and press data is utilized in searching and studying these kinds of degenerations (e.g. Sarıkaya, Funda Tuğrul and Behçetoğuları, Pembe; 1935, 1945, 1955, 1965, 1975 and 1985 Cumhuriyet newspaper Scan Research, Political Degeneration, Ankara University).

\subsection{Scope of the Research and its Limits}

Our research covers the national newspapers published in Turkey. Organizational capacities or circulation rates are not considered as scales. In this respect our research is an inventory study. The main inadequacy faced during the research was the manner of the managers of the press enterprises that were interviewed. They hesitated to answer the questions regarding ethical approaches. In this context, some of the managers and employees stated that they should have the permission of the owner of the company because the information we requested included special organizational data and they felt worried. This fact only causes an important obstacle in research. 
As our study is an organizational inventory research and we have interviewed three top and middle managers from each press enterprise.

\subsection{Method and Model of the Research}

Our research mainly examines the relation between the managerial ethics codes and ethical trainings.

Our research is an organizational inventory study and it is descriptive.

Our research is actualized with the top and middle executives of the enterprises and has a primary source research quality.

In respect of time our research is a sectional research.

\subsection{Hyphothesis of the Research}

Through our research, a hyphothesis has been progressed on the relation between the managerial ethics codes and ethical trainings of press enterprises

\section{Hyphothesis}

H0: There is no relation between having managerial ethics codes and having ethical trainings in respect of press enterprises.

H1: There is a relation between having managerial ethics codes and having ethical trainings in respect of press enterprises.

\subsection{Pre-acceptances}

In our research we tried to state the managerial ethics codes in press enterprises. We have not made any estimation on adoption of managerial ethics codes or the behaviours being appropriate or not and we have not made any ascertainments or commentations on this subject.

Declaration of a certain procedure in the press enterprises mentioned in the research does not mean that this procedure is really being applied during the operation process. For instance, a manager telling that a person informing about an unethical behaviour will be rewarded by the directorate, may act just oppositely in reality.

In conclusion, the relation between having managerial ethics codes and having ethical trainings in respect of press enterprises are examined in our research.

\subsection{Main Body}

Main body of the research is all the national press enterprises.

The press enterprises which we have interviewed the managers of are as follows:

Akşam, Birgün, Bugün, Cumhuriyet, Evrensel, Güneş, HaberTürk, Hürriyet, Milli, Milliyet, Ortadoğu, Posta, Radikal, Sabah, Star, Şok, Takvim , Taraf, Ter- 
cüman, Türkiye, Vakit, Vatan, Yeni Asya, Yeni Çă̆ , Yeni Mesaj, Yeni Şafak, Zaman, Dünya , Ekonomik Çözüm, Gözlem , Referans , Fanatik , Fotomaç Newspapers.

In this context, our research is a fullcount system and sampling method is used.

\subsection{Data Collection Method}

Questionnaires is used in this research. First of all, human resources managers of all the national press enterprises were called and informed about the research and were invited to contribute in the research.

Some of the managers of human resources hesitated in contributing when they learned that the topic of the research was managerial ethics as private institutional information was concerned. Whereupon we have made face-to-face interviews with the managers and explained them the academical content of the research and persuaded them for their contribution.

After this process questionnaires were to be answered in control of at least two (human resources and financial-administrative) managers from all the enterprises with a cross-check. E-mails were sent to the managers giving the link of the electronic questionnaires that take place in Marmara University's server and explaining the research.

Phone calls were made with the managers to explain the questionnaires and resolve misunderstandings or lack of information.

Three of the managers have declared that they should have the permission of the directorate, and consequently, this and these kinds of other situations have caused delays in data collection. And some managers have had problems in answering the questionnaires in the electronic medium, so technical support have been given to them.

Finally, the contribution percentage of the questionnaire is $100 \%$. The questionnaire is examined by two different managers separately and has been answered by them together in every enterprise mentioned.

There are 45 questions in the questionnaire. 12 of the 45 questions are related to ethical codes' occurrence. The others are related to the announcement of ethical codes in organizational process; when and by whom the codes were were improved; procedures applied in cases of code infringe; contents of the codes and updating of the codes according to the differing conditions.

Questions associated to managerial ethics training program in the questionnaire form are related to the occurrence of ethical training program, how and by whom and for whom it was realized, how often it was applied, the content and method of the training program. 
Questions associated to the reporting of unethical appliances in the questionnaire form are related to behaviour models -the way that an employee facing unethical manners would act- which come out in cases of immoral attitude.

Questions associated to the managerial ethics appliances in the questionnaire form are related to the units overtaking ethical responsibilities (ethical committees, units).

\subsection{Statistical Analysis of Data}

During the evaluation process of the knowledge collected, answers are coded with numbers and SPSS (Statistical Package for Social Sciences) for Windows 17.0 program is used for the statistical analysises.

During the evaluation process of the working data, besides definitive statistical methods (Frequency, Percentage), Pearson Ki-Kare and Fisher Exact tests are used in comparing qualitatif data.

\subsection{Validity and Reliability of the Research}

Our research is an institutional inventory study. Thus the data collected consists of consistent information of individuals and companies at the time of research. The legal institutional structure of the press enterprises is examined. Therefore, the existence of these structures is not a subjective state altering according to individual cases.

For instance, if we had asked a question as "Is the managerial informed of any demand of unethical behaviour from inside or outside the company?", the answer, according to the perception of the individual or the company, would be subjective. Whereas, through our research, we asked as, "Is there an ethical code concerning the reporting of a demand for an unethical behaviour, from inside or outside of the company?" So, we were searching for ethical codes and this is an objective case which would not differ according to individuals.

As our research is an institutional inventory study, the questionnaire was examined and answered together by at least two top managers.

"Reliability, in general saying, is related to the level of decisiveness and repetition of the results obtained at the end of an observation." (Sencer, 1989; 418)

"Validity is the range of the research reflecting the truth." (Kurtuluş, 1983;

"Reliability of the data is the probability of getting similar answers out of other evaluations realized by same methods and same procedure but by different samples from the same group." (Şencan, 2005; 12)

"To check that a surveying tool gives consistent results the same data would be measured with similar methods and techniques." (Yumlu, 1990;141) 
Based on the grounds we have explained our research has validity and reliability.

\subsection{Abstract of Research Data}

\subsubsection{Data Related to Ethical Codes}

It is found that 23 of the 33 national newspapers included in our research have ethical codes and that 10 of them do not have managerial codes.

Table: 1 Possession of Managerial Ethics Codes

\begin{tabular}{lcc}
\hline \hline & $\mathbf{n}$ & percentage \\
Companies that have managerial ethics codes & 23 & 71.4 \\
Companies that do not have managerial ethics codes & 10 & 28.6 \\
Total & 33 & 100 \\
\hline
\end{tabular}

Only 19 of the national newspapers contributing to our research that have managerial ethics codes have distributed the documents having the managerial ethics codes written on.

Table: 2 Distribution of Documents That Have Managerial Ethics Codes Written on

\begin{tabular}{lcc}
\hline & $\mathbf{n}$ & percentage \\
Companies that have distributed the documents & 19 & 67.8 \\
Companies that have not distributed the documents & 14 & 32.2 \\
TOTAL & 33 & 100
\end{tabular}

Another outcome of the research is related to the people improving managerial ethics codes.

Accordingly, it is stated that 57.7 (14 companies) percent of the press enterprises surveyed by our research that have managerial ethics codes have improved managerial ethics codes by the aid of human resources departments.

4 of the press enterprises surveyed by our research that have managerial ethics codes have improved managerial ethics codes by the aid of their employees.

Table: 3 Active Departments in the Improvement of Managerial Ethics Codes

\begin{tabular}{lcc}
\hline \hline & $\mathbf{n}$ & percentage \\
By top management & 5 & 19.2 \\
By department directors & 2 & 7.6 \\
By employees & 4 & 15.4 \\
By human resources departments & 14 & 57.8 \\
TOTAL & 25 & 100 \\
\hline
\end{tabular}




\subsubsection{Data related to Executives of Managerial Ethics}

We have reached various data related to the executives of managerial ethics as ethical committees and sections.

Only 2 of the press enterprises ( 6 percent) we have surveyed possessed a managerial ethics committee occurrence.

Table: 4 Possession of Managerial Ethics Committees

\begin{tabular}{lcc}
\hline \hline & $\mathbf{N}$ & percentage \\
Possessing companies & 2 & 6 \\
Non possessing companies & 31 & 94 \\
TOTAL & 33 & 100 \\
\hline
\end{tabular}

Besides, within the press enterprises surveyed it is stated that human resources' departments come out as the responsible unit in managerial ethics in addition to the other tasks, by a proportion of 47.2 percent (17).

Table: 5 Departments taking responsibility related to managerial ethics Data related to Unethical Appliance Reports and Sanctions

Top Management

Inspectorate / Internal Inspection

Managers of Departments

Nobody / departmnet

TOTAL

percentage

\begin{tabular}{rc}
\multicolumn{1}{c}{ n } & percentage \\
17 & 68 \\
3 & 12 \\
1 & 4 \\
1 & 4 \\
3 & 12 \\
25 & 100
\end{tabular}

We asked the contributors if they were able to report the unethical behaviours to the top management. It was stated that only 19 companies had given this possibility.

Table: 6 Companies That Provide the Possibility to Report the Unethical Behaviour to the Topmanagement

Companies providing that possibility

Companies not providing that possibility

TOTAL

$\begin{array}{cc}\text { n } & \text { percentage } \\ 19 & 58 \\ 14 & 42 \\ 33 & 100\end{array}$

In this context, we also asked the contributors what was the expected application in case of an employee reporting an unethical behaviour. The data reached at the end was interesting: 33.3 percentages of the contributor companies did not know what was going to be done. 19 companies declared that the reporter was going to be secured. Only 3 companies had an awarding system for this case. 
Tablo: 7 Applications Orientated to the Person Reporting Unethical Behaviour to Top Management

\begin{tabular}{lrc}
\hline \hline & $\mathbf{N}$ & percentage \\
Awarded & 3 & 58 \\
Protected & 19 & \\
Suffered & 1 & 42 \\
Ambigiuous & 10 & 100 \\
TOTAL & 33 & \\
\hline
\end{tabular}

\subsubsection{Data Received Related to Managerial Ethics Training}

At the end of the survey it is found that none of the companies contributed had a special managerial ethics training program. Only 8 of them have stated that they have included ethics in the existing training program.

25 (76 percentages) companies do not have ethical training at all.

Table: 8 Managerial Ethics Training Occurrence

\begin{tabular}{lcc}
\hline \hline & N & percentage \\
Special managerial ethics training & - & 0 \\
Managerial ethics included in the existent training & 8 & 24 \\
Companies having not managerial ethics training & 25 & 76 \\
TOTAL & 33 & 100 \\
\hline Another study included in our research was about the people who were given \\
managerial ethics trainings. 8 companies possessing managerial ethics codes gave \\
Table: 9 Managerial Ethics Trainings Orientation \\
- thical training to all their employees. \\
Orientated to all employees \\
Orientated to management \\
Orientated to department managers \\
TOTAL \\
\hline \hline
\end{tabular}

During our research we also asked questions related to the content of the ethical training. 7 companies explained general ethical philosophy in the scope of ethical training.

Table: 10 Content of Managerial Ethics Training

\begin{tabular}{lcc}
\hline \hline & $\mathbf{n}$ & percentage \\
Explanation of institutional ethics philosophy & 7 & 100 \\
Explanation of general press ethics & 0 & \\
Explanation of behaviours that are unethical and & & \\
that are not preferred & 0 & 100 \\
TOTAL & 7 & \\
\hline
\end{tabular}




\subsubsection{Data Found Related to the Research Hypothesis}

Our research hypothesis is related to the relation between managerial ethics codes and managerial ethics training.

At the end of the analysis a correlation coefficient of 0.27 is achieved. This coefficient shows that there is very small relation between press enterprises having ethical codes and ethical training. In this case we accept that the hypothesis HO, suggesting that there is no relation between press enterprises having ethical codes and ethical training, is correct.

It is comprehended that there is not a significant relation between having ethical codes that define the wanted and unwanted behaviour in respect of managerial ethics and the training programs that are created on ethics. (Ki-Kare $=0.95$; Fisher exact $\mathrm{p}=0.320$ )

\section{Valuation and Conclusion}

Managerial ethics concerns not only the business life (workers/consumers) but all the people and the environment. In this respect, managerial ethics has a significant function in solving and/or obstructing the problems and conflicts during the socia- economic process.

John Rawls (1921- 2002) has brought a new approach for the moral evaluation of the social and political enterprises by using the basics of both philosophies of Utilitarians and Kant. Rawls, as avoiding from the difficulties of teleology and deontology has come up with a moral theory which tries to use the prominent part of these theories.

According to justice approach in order to say that the moral principles are considered while deciding, the decision process should be equal, just and neutral. (Daft, 1997; 145)

The importance and emphasis of the managerial ethics concerning social benefits is the basic dynamics of the improvement of social responsibility consciousness relating to enterprises. Social responsibility perception necessitates on organization that cares about employees, consumers, shareholders and environment in the way that business ethics demands.

As we have mentioned before, there are various researches (academical studies, surveys made by the related institutions) made on proffesion of journalism under the title of media ethics. But there is not a specialized study on the occurrence and appliance of managerial ethics programs related to the press enterprises' managing procedure. The research we have accomplished in this respect is a unique survey that defines the managerial ethics programs and their applications and the occurrence of managerial ethics training programs related to press enterprises. 
As mentioned in the chapters above, it is necessary to have an active contribution of all the employees to the process of managerial ethics programs being realized and applied in an enterprise.

But, according to Cooper, Traditional organizational structures and management ideas cause failures in creating ethical codes contributively, in improving working people and in encouraging of ethical behaviour. (Cooper, 2004; 400)

Another prerequisite for the successful application of managerial ethics program in an organization is the existence and continiuty of the managerial ethics training programs. Without doubt, the existence of ethical codes determined and written by top management does not mean that the enterprise has the culture and application ability related to managerial ethics. It is essential to create ethical codes with a participant way of managing apprehension as well as the organized training program for the success and the application sincerety.

For instance, according to Rachman, It is important for the organizations to create a suitable atmosphere for the reporting process of unethical behaviour to be realized in order to carry on their organization according to the moral values. (Rachman, 1996; 90)

Therefore in our research, besides stating whether the press enterprises have managerial ethics codes or not, we also tried to determine if the press enterprises declaring that they have managerial ethics codes have special managerial ethics training programs.

Because, according to Kreitner, Officials and volunteers of ethics in organizations state that individuals should support the superior management in carrying out the work in the scope of business ethics concerning the appliance of managerial ethics. (Kreitner, 1995; 154)

According to our research it is found out that there is not a significant relation between having ethical codes that define the wanted and unwanted behaviour in respect of the managerial ethics and the training programs that are created on ethics. This is also valid for the new personnel.

The outcome of this research is that 23 out of the 33 of the press enterprises contributing to the survey have declared that they have managerial ethics codes but that none of them had special managerial ethics training programs.

Positively, we can put forward at this point a commentation depending on the results of the research: The submission hasn't been carried out sincerely throughout the creation and application process of the managerial ethics program in the press enterprises which declared that they have managerial ethics codes and contribution is not well adopted. The lack of payment for managerial ethics training programs is a confirmation of this conclusion. The fact that only two of the press enterprises having managerial ethics commitees also shows the meaning of the application of 
managerial ethics programs for the press enterprises during the research process. Since, as explained in above chapters the existence of managerial ethics committees is essential in application of managerial ethics programs and the success of the application.

Another important outcome of our research is the statement of people who improve the managerial ethics codes. Thus, in 57.7 (14 companies) percent of the the press enterprises having managerial ethics codes that are the subject of our research has been improved by the human resources departments.

Only 4 of the managerial ethics codes having press enterprises have improved these codes with the active contribution of their employees.

Throughout the research, we also asked the contributors what was the expected reaction in case of an employee reporting an unethical behaviour. The data reached at the end was interesting: 33.3 percentages of the contributor companies did not know what was going to be done.

As known, press enterprises in democratical societies have an important social function named as the $4^{\text {th }}$ Force. These press enterprises that perform a public service have an important communal responsibility as the formation and socialization of knowledge and news.

In this context, the press enterprises having an important function as informing the public of unethical behaviours and applications in the economical and social world. Thus, it is essential to know whether they have managerial ethics applications or not in their managerial process.

Consequently, to state the accordance of the press enterprises that have the strength to produce political and cultural effect on public, with the managerial ethics concept throughout the management process, will surely have an important influence on the argument of the subject in context of social agenda.

The general conclusion reached after the evaluation of our research is as follows: It is found that only 23 of the 33 national newspapers included in our research have ethical codes, and even these enterprises do not apply or carry out these managerial ethics programs with care and sincerity. It is also found out that these enterprises do not spend enough time on this process and they do not have enough supply in their budget for it and thus, do not have any controls or estimations made on managerial ethics as they do not have a related program.

Besides, press enterprises cannot be considered free from social-economical conditions as all the economical components of the society. Thus it is not possible to think that ethics can change magicly all the negative formation at once without having a significant change in social-economical situation. 
All the same, as being so effective on social life, press enterprises should pay the necessary importance to managerial ethics and should sincerely and carefully utilize the existent methods through their organizational process.

\section{References}

ALDAG, Ramon J, STEARNS, Timothy M. (1991), Management, Second Ed., Cincinatti, Ohio: Sounth Western Publishing.

ARSLAN, Mahmut, BERKMAN, Ümit (2009), Dünyada ve Türkiye'de İş Etiği ve Etik Yönetimi, TUSİAD / T-2009-06-492, İstanbul.

BARTOL, Kathryn, David C. MARTIN (1994) Management, New York, McGraw Hill Inc.

CARROLL, A B. (1991), “The Pyramid of Corporate Social Responsibility: Toward the Moral Management of Organizational Stakeholders", Business Horizons

COOPER, Terry L (2004), "Big Questions in Administrative Ethics: A Needfor Focesed, Collaborative Effort", Public Administration Review, July / August, Vol. 64, No. 4

ÇALIŞLAR, Aziz (1983), Ansiklopedik Kültür Sözlüğü, İstanbul, Altın Kitaplar Yayınevi

DAĞDELEN, İlhan (2005), "Managerial Ethics”, Mevzuat Dergisi, Y1l: 8, Say1: 90 .

DAFT Richard (1997), Management, The Dryden Press, Fourth Edition

DEMİR, Hulusi, SONGÜR, Neşe (1999), "Sosyal Sorumluluk ve İş Ahlakı", Balıkesir Üniversitesi, Sosyal Bilimler Enstitüsü Dergisi, Cilt: 2 Sayı: 3

FLIPPO, Edwin, GARY B, MUNSINGER, M (1982), Management, Boston, Allyn and Bacon.

GREENBERG J, BARON A. Robert (1997), Behavior in Organization Understanding and Managing the Human Side of Work, New Jersey, Prentice.

Hall, JUBB P.B. (1996), "On the Definition of Whistleblowing and its Applicability to the Accountants' Audit Function", International Society of Business, Economics and Ethics, Tokyo, http // www.nd.edu/isbee/p-jubb.htm

KHERA, Inder P. (2001), "Business Ethics East vs.West: Myths and Realities", Journal of Business Ethics.

KIREL, Çiğdem (2000), “Örgütlerde Etik Davranışlar Yönetimi ve Bir Uygulama Çalışması”, Anadolu Üniversitesi Yayınları, Eskişehir. 
KOHLBERG, Lawrence (1981), The Philosophy of Moral Development: Moral Stages and the Idea of Justice, (Essays on Moral development), Volume I, Harper \& Row PublishersI

KREITNER, Robert (1995), Management, Boston, Houghton Mifflin

KURTULUŞ, Kemal (1983), İşletmelerde Araştırma Yöntembilimi, İstanbul Üniversitesi Yayın No: 3128, İşletme Fakültesi yayın No: 145, İşletme İktisadı Enstitüsü Yayın No: 63, İstanbul.

LAMBERTON, Lowell H, MINOR Leslie (1995), Human Relations: Strategies For Success, Chicago, Irwin Mirror Press.

LEWIS, Pamela, GOODMAN H. Stephen, FANDT M. Patricia (1995), Management Challengers in the 21st Century, st. Paul, West Publishig

MCNAMARA, Carter (2002), Complete Guide to Ethics Management: An Ethics Toolkits for Managers, (Çevrimiçi), http//www.mapnp.org/library/ethics/ ethxgde.htm,05.

MESCON, Micheal H, MUCHEAL, Albert, KHEDOURI F (1988), Management, new York, Harper \& Row

MOSLEY, Donald C, P.H PIETRI, L.C MEGGINSON (1996), Management Leadership in Action, New York, Harper Collins.

NAHAVANDI, Afsaneh, MAEKZADEH, A.R (1999), Organizational Behavior the Person - Organization Fit, New Jersey, Prentice Hall.

NALBANT, Eser, (2005), "İşletmelerde Sosyal Sorumluluk ve İş Ahlakı", Yönetim ve Ekonomi Dergisi, Cilt: 12 Say1:1, Celal Bayar Üniversitesi, İ.İ.B.F Manisa.

ÖZGENER, Şevki (2009), İş Ahlakının temelleri: Yönetsel Bir Yaklaşım, Nobel Yayın Dağıtım, Ankara.

ÖZGEN, Murat (2006), Gazetecinin Etik Kimliğgi, Genişletilmiş 3. Basım, Set Systems Tercümanlık Reklamcılık Yayıncılık Ltd.

ÖZKOL Sedat (2007), 7-e Paradigması, Hayat Yayıncılık

RACHMAN David J. (1996), Business Today, 8.bs McGraw Hill.

ROBBINS, Stephen, COULTER, M (1999), "Management” 6. Bs, New Jersey, Prentice Hall.

SAYINER, Mehmet Anıl (2005), Managerial ethics Kavramının Örgütlerde Uygulanmas1, Yüksek Lisans Tezi, İstanbul Üniversitesi, Sosyal Bilimler Enstitüsü 
SAYLI, Halil, KIZILDAĞ, Duygu (2007), "Managerial ethics ve Yönetsel Etiğin Oluşmasında İnsan Kaynakları Yönetiminin Rolünü Belirlemeye Yönelik Bir Analiz" Afyon Kocatepe Üniversitesi Sosyal Bilimler Dergisi

SCHERMERHORN, John R., (1989). Management for Productivity, ThirdEdition, Carbondale: Southern Illionis John Willey \& Sons Inc.

SENCER, Muzaffer (1989), Toplum Bilimlerinde Yöntem, Beta Basım Yayım Dağıtım, İstanbul

ŞENCAN, Hüner (2005), Sosyal ve Davranışsal Ölçümlerde Güvenirlik ve Geçerlilik, Seçkin Yayıncılık, Ankara

TOOFFLER, Barbara (1986), Tough Choices, Managers Talk Ethics, NewYork, John Wiley\&Sons Inc.

UZUN, Ruhdan (2009), İletişim Etiği: Sorunlar ve Sorumluluklar, Dipnot Yayınları, Ankara

ÜLGEN, Arzu (2003), Global Etik ve Global İşletmelerde Uygulanan Etik Yaklaşımlar Üzerine Bir Araştırma, Doktora Tezi, İstanbul Üniversitesi, Sosyal Bilimler Enstitüsü

YUMLU, Konca (1994), Kitle İletişim Kuram ve Araştırmaları, Nam Basım Ltd, İzmir. 
